\title{
Integration of urban developers with regard to social and environmental responsibility
}

\author{
Irina Nuzhina ${ }^{1,2, *}$, Maria Zolotareva ${ }^{1}$, and Iuliia Vasileva ${ }^{1}$ \\ ${ }^{1}$ Tomsk State University of Architecture and Building, 634003 Tomsk, Russia \\ ${ }^{2}$ Tomsk State University of Control Systems and Radioelectronics, 634050 Tomsk, Russia
}

\begin{abstract}
The aim of this study is to develop a model for institutionalizing the social and environmental responsibility of the construction business as an important factor in the modern urban development. Methods of systems, logical and comparative analysis, as well as a questionnaire survey are used in the research. Based on the situation in Tomsk (Russia), public preferences and needs for construction products have been examined taking into account environmental friendliness and the quality of the urban environment. The results of the examination are presented in this paper. The study reveals the public need for building products and shows how these needs are related to greening the construction industry and developing the social and environmental responsibility of the construction business. The green urban development needs an environmentally sustainable regulation mechanism based on appropriate methods, tools and organizational forms of interactions between stakeholders in the construction industry. A concept for managing interactions between stakeholders in urban development is proposed on the basis of the ECOURBANBUILD platform. The integration based on this platform will create additional opportunities to implement the social and environmental responsibility of the construction business in the interests of sustainable urban development.
\end{abstract}

\section{Introduction}

Throughout the world, the absolute priority in urban development is to create a safe and comfortable environment for human beings, which is closely tied to environmental conditions and quality of life $[1,2]$. Therefore, it is a matter of urgency to search for effective mechanisms for regulating urban development that will ensure socially and environmentally acceptable territorial development, and increase the environmental performance of the entire economic system. According to the Environmental Performance Index 2016, Finland is the greenest country in the world. The other top ten countries are Iceland, Sweden, Denmark, Slovenia, Spain, Portugal, Estonia, Malta, and France. Russia ranks 32 nd among 180 countries in the index and has improved its ranking by $24 \%$ in the previous two years [3].

\footnotetext{
* Corresponding author: irinanuzhina@yandex.ru
} 
There are also annual environmental ratings for various Russian regions. As of May 1, 2017, the Tomsk Region has ranked 22nd among 86 regions of the Russian Federation. In the Siberian Federal District (SFO), the Tomsk Region is second only to the Altai Republic and the Altai Krai [4].

Urban planning has a direct bearing on environmental rankings of territories. Socioenvironmental aspects of urban planning are studied on an interdisciplinary basis. Problems of environmental support for urban planning are discussed in Plotnikova (2008) and Krygina (2015). Environmental safety of construction and management is considered in Telichenkoetal (2016). Greening of industries and environmental innovations are addressed in Morgunovetal. (2017), Chuanqi (2012), Rudneva et al. (2016), Zakharova et al. (2015), Kasianenko et al. (2015). Sustainable development problems in construction and architecture, as well as the development of environmental infrastructure are investigated in Tetior (2008). Social aspects of urban development are considered in Grabovyy (2016), Pakhomova et al. (2008) [5-11].

However, institutionalization of social and environmental responsibility of the construction business has yet to be fully explored both in theory and in practice. Methods and tools for regulating the construction industry should be aimed at achieving socially and environmentally significant results.

This paper concerns institutionalization of the social and environmental responsibility of the construction business, and aims to determine the nature of this process and structure it, as well as to develop a conceptual model for managing the integrated interactions between stakeholders in urban development as a key factor in greening the construction regulation mechanism. For these purposes, the paper demonstrates the importance of the environmental factor for society and the urban environment, examines the nature and content of the social and environmental responsibility of the construction business, identifies public preferences and the need for building products.

\section{Research Methods}

The theoretical and methodological framework of the research is based on provisions of the institutional theory [12-14], works by Russian and foreign scientists and specialists addressing problems of regulation in the field of urban development, taking into account environmental factors, environmental and economic support for construction activities [7$9,11]$.

Data from Russian and foreign statistical systems serves as a basis for the research. These are Eurostat, the Unified Interdepartmental Information and Statistical System (UISIS), Rosstat (Federal State Statistics Service of Russia), Tomskstat (Territorial Body of the Federal State Statistics Service in the Tomsk Region), UN reports and publications, Cities Alliance, All-Russia Public Opinion Research Center, and other Russian and foreign organizations. [4, 15-24].

When elaborating the problematic issues stated in the paper, we relied on opinion polls about the comfort level of the urban environment $[16,18,20]$, a questionnaire survey to identify public preferences and the need for building products [21], the method of systematic and comparative economic analysis [25], as well as statistical data processing methods [26].

\section{Research Materials}

The human environment is a result of transformations in the field of urban development and closely tied to social (socio-psychological and socio-economic) factors of societal 
development. The awareness of the fact that consequences of construction activities are relevant to the environment determines the priorities of the modern urban development in territorial entities of Russia. These priorities include the availability of housing and housing services; availability and accessibility of social and infrastructural facilities, the creation of a comfortable, accessible and safe environment; availability of facilities that contribute to socialization, communication and recreation; preservation of natural landscapes; preservation of cultural, historical and architectural monuments; architectural expression and aesthetic appearance of facilities; application of environmentally friendly materials, technologies, engineering equipment and systems; energy efficiency and resource saving in construction and maintenance of facilities; use of "inconvenient" and "unattractive" areas; integrated housing development [23].

The fully-fledged environmentally oriented development of the construction sector is possible only by institutionalizing and developing the social and environmental responsibility mechanism of the construction business. The social and environmental responsibility mechanism for the construction business is a deliberate initiative of construction companies aimed at adopting additional, stricter social and environmental requirements for investment and construction projects, as well as at complying with mandatory environmental requirements, regulations and standards in the construction sector [23]. Construction companies go beyond the regulatory and legal framework, and initiate the adoption of additional, stricter social and environmental requirements to production activities and their results (products, services, work).

It is the institutional environment that creates opportunities for developing the construction business in an environmentally and socially sustainable manner. The institutional environment provides conditions for the functioning of construction companies and, therefore, affects the economic, environmental and social performance [23].

Public opinion polls make an important contribution to the promotion of green building $[16,18]$. For example, since 2004, Eurobarometer has been conducting Quality of Life in European Cities surveys every three years [20]. Similar surveys are conducted in Russia. On April 20, 2017, the All-Russia Public Opinion Research Center presented the results of monitoring in the field of environment and landscaping. According to the survey, citizens are primarily concerned about problems of landscaping in the urban environment and areas adjacent to their houses. These problems include garbage generation (23\%); condition of roads and traffic jams $(22 \%)$; a large number of cars and a shortage of parking lots $(12 \%)$; children's playgrounds (8\%), and lack of green spaces $(6 \%)$ [22].

In order to identify preferences and needs of citizens for eco-friendly building products, the authors conducted a questionnaire survey of Tomsk residents (200 respondents). Respondents were asked to assess the social and ecological environment of the city by identifying the three most significant factors that determined their dissatisfaction with the entire urban environment and the environment of their residential district (Table 1).

According to the survey, $57 \%$ of respondents are not satisfied with the quality of the environment in their districts and would like to move to another district with a more developed social infrastructure and a more favorable environmental situation. $62 \%$ of respondents are willing to make a choice in favor of a more eco-friendly and expensive house. This group is mainly represented by employees and managers aged 25 to 40 years. $79 \%$ of respondents would prefer to choose a house made of eco-friendly building materials. 
Table 1. Analysis of Survey Results.

\begin{tabular}{|c|c|c|c|c|c|c|c|c|c|c|c|c|c|c|}
\hline & \multicolumn{14}{|c|}{ Socio-demographic characteristics of respondents } \\
\hline & \multicolumn{2}{|c|}{ Sex } & \multicolumn{4}{|c|}{ Age } & \multicolumn{4}{|c|}{ Occupation } & \multicolumn{3}{|c|}{\begin{tabular}{|c|} 
Household \\
income level
\end{tabular}} & \multirow{3}{*}{ 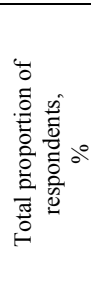 } \\
\hline & $\frac{0}{\pi}$ & 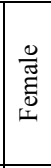 & 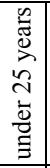 & 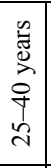 & $\begin{array}{l}0 \\
\tilde{\Xi} \\
\grave{8} \\
0 \\
0 \\
o \\
+\end{array}$ & 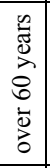 & 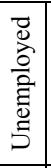 & 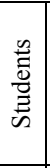 & 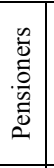 & 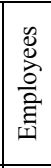 & 草 & 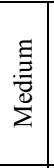 & $\stackrel{5}{b 0}$ & \\
\hline Proportion of respondents, $\%$ & 43 & 57 & 33 & 42 & 20 & 5 & 6 & 43 & 11 & 40 & 34 & 43 & 13 & \\
\hline \multicolumn{15}{|c|}{ Dissatisfaction with the city's social and ecological environment. } \\
\hline Sanitary condition of streets & 47 & 53 & 42 & 26 & 8 & 8 & 18 & 37 & 5 & 39 & 29 & 53 & 18 & 63 \\
\hline $\begin{array}{l}\text { Landscaping and gardening of the urban } \\
\text { environment }\end{array}$ & 37 & 63 & 39 & 29 & 32 & 0 & 0 & 34 & 21 & 45 & 39 & 37 & 24 & 57 \\
\hline Architectural appearance of buildings & 50 & 50 & 0 & 75 & 25 & 0 & 0 & 25 & 38 & 38 & 0 & 50 & 50 & 50 \\
\hline Condition of tourist zones & 43 & 57 & 30 & 57 & 13 & 0 & 11 & 28 & 21 & 40 & 24 & 58 & 18 & 53 \\
\hline Too much outdoor advertising & 69 & 31 & 8 & 54 & 38 & 0 & 15 & 19 & 27 & 38 & 23 & 58 & 19 & 78 \\
\hline \multicolumn{15}{|c|}{ Dissatisfaction with the social and ecological environment in the residential district. } \\
\hline Sanitary condition of yards & 53 & 47 & 42 & 24 & 29 & 5 & 24 & 16 & 32 & 29 & 26 & 71 & 3 & 86 \\
\hline $\begin{array}{l}\text { Landscaping and gardening of areas adjacent } \\
\text { to the house }\end{array}$ & 48 & 52 & 26 & 38 & 33 & 2 & 24 & 43 & 29 & 5 & 26 & 45 & 17 & 63 \\
\hline Architectural appearance of buildings & 38 & 31 & 22 & 53 & 19 & 0 & 13 & 31 & 41 & 16 & 22 & 44 & 22 & 36 \\
\hline Lack of organized parking areas & 53 & 47 & 28 & 47 & 25 & 0 & 0 & 14 & 22 & 64 & 19 & 56 & 25 & 73 \\
\hline $\begin{array}{l}\text { Lack of social infrastructure facilities in } \\
\text { walking distance }\end{array}$ & 63 & 37 & 35 & 40 & 25 & 0 & 13 & 27 & 38 & 21 & 17 & 67 & 15 & 42 \\
\hline \multicolumn{15}{|c|}{ Choice of respondents (subject to the availability of financial resources) } \\
\hline $\begin{array}{l}\text { Moving to another city with a more } \\
\text { developed social and environmental } \\
\text { infrastructure }\end{array}$ & 50 & 50 & 25 & 47 & 28 & 0 & 9 & 9 & 56 & 25 & 13 & 50 & 38 & 16 \\
\hline $\begin{array}{l}\text { Moving to a district with more developed } \\
\text { social and environmental infrastructure }\end{array}$ & 49 & 51 & 37 & 42 & 21 & 2 & 8 & 22 & 29 & 41 & 31 & 57 & 9 & 43 \\
\hline $\begin{array}{l}\text { Investing money in developing my district } \\
\text { through modern forms of management }\end{array}$ & 27 & 73 & 27 & 29 & 44 & 2 & 13 & 15 & 52 & 21 & 6 & 67 & 27 & 24 \\
\hline I am satisfied with everything & 54 & 46 & 75 & 13 & 13 & 0 & 33 & 25 & 29 & 13 & 8 & 75 & 17 & 12 \\
\hline $\begin{array}{l}\text { I wish a lot of things were different but I } \\
\text { don't see a chance to change something. }\end{array}$ & 58 & 42 & 50 & 33 & 17 & 0 & 17 & 17 & 58 & 8 & 75 & 25 & 0 & 6 \\
\hline
\end{tabular}

Certainly, the ability to meet the public needs for eco-friendly building products depends on the level of household income. The price (five points) is the determining factor for respondents with low household income (up to $\$ 1,000$ per month), while high-income respondents give priority to the environmental situation in their districts, comfortable environment, and availability of recreational zones (Table 2).

Table 2. Importance of factors that influence the choice of housing (points), based on the survey results.

\begin{tabular}{|l|c|c|c|}
\hline \multirow{2}{*}{ Factors } & \multicolumn{3}{c|}{ Average household income } \\
\cline { 2 - 4 } & low & medium & high \\
\hline Environmental situation in the microdistrict & 2.5 & 3.9 & 5 \\
\hline $\begin{array}{l}\text { Use of eco-friendly materials and energy-saving } \\
\text { technologies }\end{array}$ & 3.8 & 3.8 & 4 \\
\hline Proximity to the city center & 3.8 & 2.6 & 2 \\
\hline Infrastructure, transport accessibility & 3.8 & 2.6 & 2 \\
\hline Price & 5 & 3 & 1.6 \\
\hline $\begin{array}{l}\text { Comfortable environment, proximity to the } \\
\text { recreational area }\end{array}$ & 2.4 & 4.3 & 5 \\
\hline
\end{tabular}


Thus, in order to create a modern environmentally sustainable space in urban areas, an adequate system of methods and tools for regulating urban development must be available. These methods and tools are aimed at institutionalizing the social and environmental responsibility mechanism for the construction business, as well as at developing appropriate legal regulations and voluntary initiatives that would be proposed by the government and the business, and supported by civil society.

The institutionalization of the social and environmental responsibility mechanism for the construction business is the process of defining formal rules and informal restrictions, establishing institutions and organizational forms of interaction between stakeholders in construction investment, environmental and economic regulation, and developing interrelations that ensure the achievement of objectives subject to social and environmental priorities of territorial development. Introduction of an environmentally sustainable mechanism for regulating construction investment activities is the key element of the institutionalization process [23].

\section{Results}

In the context of greening, the mechanism for regulating construction investment activities should be considered as a system of organizational forms of interaction between stakeholders in construction investment activities, methods and tools to influence the economic behavior of these stakeholders. The purpose of this mechanism is to harmonize economic interests with social and environmental requirements for territorial development. One of the most important current tasks is to develop a model for integrated management of interactions between stakeholders in urban development aimed at coordinating efforts of scientific institutes, the government, business and society in addressing social and environmental problems of urban areas. The methodological principles of integrated interaction include goal orientation, sufficiency, readily available, consistent information and analytical support, competence in decision-making, flexibility and adaptability, a variety of solutions to choose from, and recognition of the life cycle of building products.

In implementing these principles of integrated interaction, one of the most acceptable options is to create "platforms" for solving urgent problems, independent and professional expert reviews, cooperation of commercial and non-profit organizations and the government in various fields.

The creation of the ECOURBANBUILD platform is considered to be a reasonable solution for regulating the economic behavior of stakeholders in construction investment activities with the aim of ensuring environmentally acceptable and socially oriented development of the construction investment sector. This platform is a mechanism aimed at mobilizing initiatives of the construction business, the government, civil society institutions, and other stakeholders in developing an architectural and urban environment that is both eco-friendly and favorable for the human and social development. The platform brings together enterprises, organizations and associations from various sectors that share goals and objectives of the platform, and contribute to their achievement.

The conceptual model of the proposed ECOURBANBUILD platform is presented in Figure 1. The ECOURBANBUILD platform designed for environmentally sustainable urban development should be implemented in all regions. The institutional component includes location, an organizational management structure, working and expert groups, a strategic research and implementation program, a roadmap for achieving short-term and long-term goals. 


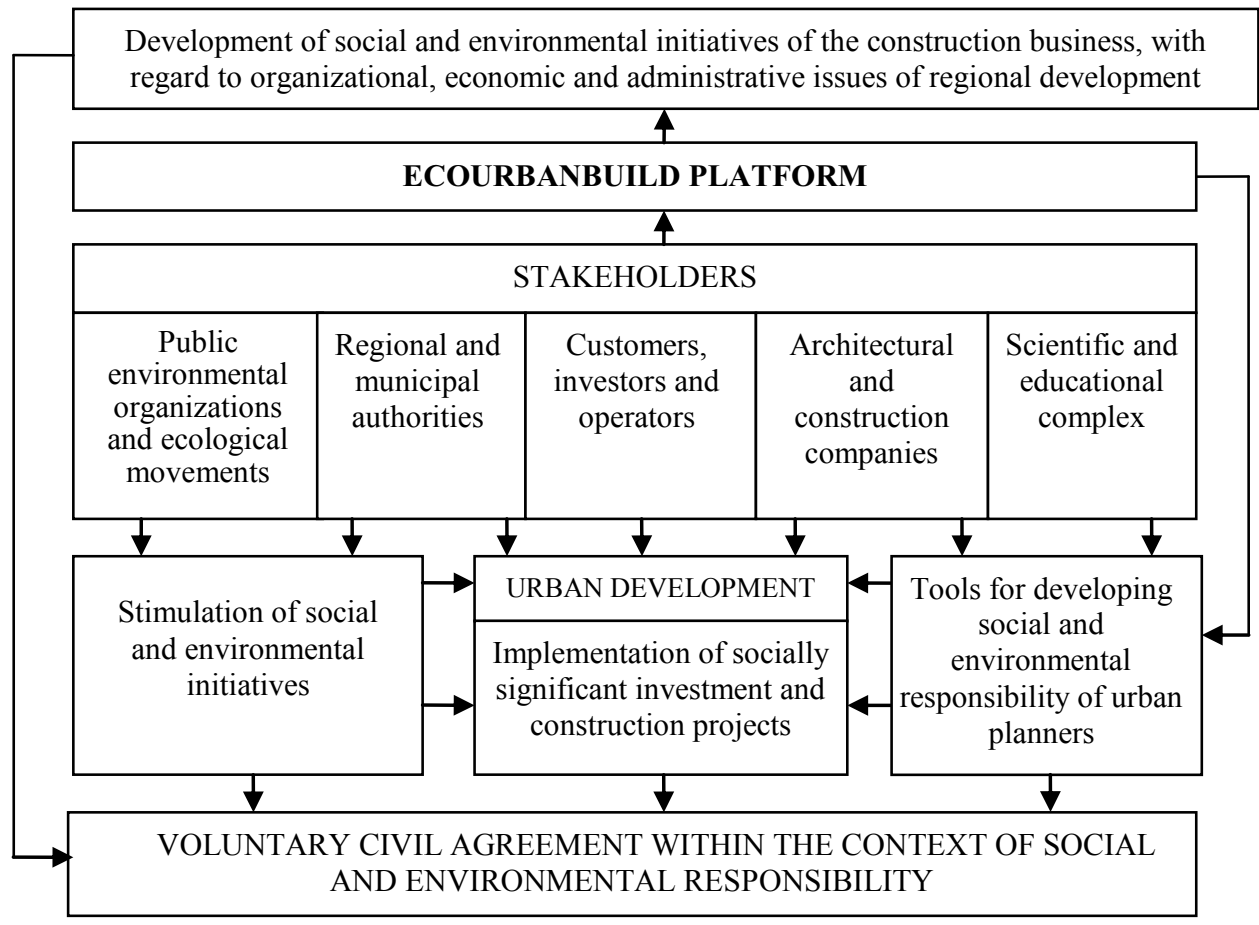

Fig. 1. The conceptual model for managing integrated interactions between stakeholders in construction investment activities, based on the ECOURBANBUILD platform (developed by the authors).

This model for managing integrated interactions between stakeholders in construction investment activities will create additional opportunities for promoting the development of social and environmental initiatives for the benefit of individuals and society as a whole.

\section{Conclusion}

A modern urban development model should be created under the dominant influence of social and environmental factors of territorial development reflecting the needs of citizens for more eco-friendly building products. The fully-fledged environmentally sustainable development of the construction business is possible only by introducing green methods and tools to regulate construction investment activities, as well as by improving organizational forms of interactions between urban development stakeholders, including the government, business and society.

Using ECOURBANBUILD as a platform for interactions, it is possible to reduce transaction costs for coordinating interests and business negotiations of stakeholders in investment and construction projects, exchange of information and disseminating experience in the field of green building, as well as to prevent possible consequences of decision-making without agreeing on controversial issues with potential consumers and the public, to exclude models of construction processes that negatively affect the environment and society.

The practical significance of this study is associated with the possibility and feasibility of using the proposed model for managing integrated interactions between stakeholders in construction and investment activities on the basis of the ECOURBANBUILD platform in 
the field of urban development regulation, while implementing socially significant investment projects.

The paper was funded by the Russian Foundation for Basic Research (RFBR) under the research project No. 16-32-00005a: Modeling of Management Techniques Aimed at Implementing Social and Environmental Responsibility of the Construction Business.

\section{References}

1. V.V. Buzyrev, I.P. Nuzhina, Ekologo-ekonomicheskie aspekty investicionnostroitel'noj dejatel'nosti [Ecological and economic aspects of investment and construction activities] (Saint Petersburg State University of Engineering and Economics, Saint Petersburg, 2012) (in Russian)

2. WWW-LAFAGERHOLCIM-FOUNDATION, Understanding sustainable construction, available at: https://www.lafargeholcimfoundation.org/AboutPages/what-is-sustainable-construction/ (2014)

3. WWW-GTMARKET, Rating of countries in the world in terms of environmental performance in 2016, available at: http://gtmarket.ru/news/2016/01/29/7292/(2016) (in Russian)

4. WWW-GREENPATROL, Environmental rating of the subjects of the Russian Federation, available at: http://www.greenpatrol.ru/ru/stranica-dlya-obshchegoreytinga/ekologicheskiy-reyting-subektov-rf?tid=291 (2016) (in Russian)

5. L.V. Plotnikova, Ekologija megapolisa [Ecology of a metropolis] (Association of Civil Engineering Universities, Moscow, 2008) (in Russian)

6. A.M. Krygina Zhilishchnoe Stroitelstvo [Housing Construction], 6, 57 (2015) (in Russian)

7. V.I. Telichenko, A.A. Benuzh, Vestnik of MGSU, 1, 118 (2016)

8. H. Chuanqi, Modernization science, 472-476 (2012)

9. A.N. Tetior, Prirodoobustrojstvo [Environmental Engineering], 2, $57-67$ (2008) (in Russian)

10. P.G. Graboviy, Real estate: economics, management, 4, 12-19 (2016) (in Russian)

11. N.V. Pahomova, G.B. Malyshkov, Problems of modern Economics, 2, 310-317 (2008) (in Russian)

12. D. North, Questions of Economics, 3, 6-17 (1997)

13. N.A. Asaul, Institucional'noe vzaimodejstvie subjektov investicionno-stroitel'nogo kompleksa [Institutional interaction of the subjects of the investment and construction complex] (Gumanistika, Saint Petersburg, 2005) (in Russian)

14. E.G. Matjugina, Institucionalizacija nacional'nyh jekologo-jekonomicheskih otnoshenij kak faktor obespechenija ustojchivosti razvitija hozjajstvennoj sistemy [Institutionalization of national ecological and economic relations as a factor in ensuring the development sustainability of the economic system] (TSUAB Pabl., Tomsk, 2006) (in Russian)

15. WWW-CONSTRUCTINGEXCELLENCE, Corporate Social Responsibility, available at:http://constructingexcellence.org.uk/wp-

content/uploads/2015/03/social_responsibility.pdf/ (2016)

16. WWW-EC.EUROPA, "Quality of Life in European Cities," report, European Commission, Directorate-General for Regional and Urban Policy, available at: http://ec.europa.eu/regional_policy/sources/docgener/studies/pdf/urban/survey2015_e n.pdf/ (2015)

17. M. Lowe, C. Whitzman, H. Badland, M. Davern, L. Aye, D. Hes, I. Butterworth, B. Giles-Corti, Urban Policy and Research, 33(2), 131-144 (2015) 
18. WWW-CITIESALLIANCE, "Liveable cities. The benefits of urban environmental planning", report, The Cities Alliance, available at: http://www.citiesalliance.org/sites/citiesalliance.org/files/CA_Docs/resources/cds/live able/liveablecities web 7dec07.pdf/ (2007)

19. WWW-UN-DOCUMENT, "The urban challenge in developing countries", report, World Commission on Environment and Development, United Nations, available at: http://www.un-documents.net/ocf-09.htm (2015)

20. WWW-WCIOM, "Ekologicheskaja situacija: monitoring" [Ecological situation: monitoring] available at: https://wciom.ru/index.php?id=236\&uid=116167 (2017) (in Russian)

21. WWW-WCRC, "Proekt realizacii tehnologicheskoj platformy "Tehnologii ekologicheskogo razvitija" [Project for the implementation of the technological platform "Technologies for Environmental Development, Russian Geographical Society, available at: http://www.wcrc.ru/TP.pdf/ (2011) (in Russian)

22. I.P. Nuzhina, M.V. Zolotareva, Yu.V. Vasileva, Basic research, 12(2), 447-452 (2016) (in Russian)

23. I.P. Nuzhina, M.V. Zolotareva, Journal of Economy and entrepreneurship, 12-1, 945953 (2016) (in Russian)

24. I.S. Godenov, Evropejskie tehnologicheskie platformy [European technological platforms] (TSU, Tomsk, 2011) (in Russian)

25. F.I. Peregudov, F.P. Tarasenko, Osnovy sistemnogo analiza [Fundamentals of system analysis], 3, 396 (2001) (in Russian)

26. N.A. Yarushkina, Optimizacija sistemy gradostroitel'stva na osnove informacionnoanaliticheskogo podhoda [Optimization of the urban planning system based on the information-analytical approach] (TSUAB Pabl., Tomsk, 2013) (in Russian) 